\title{
Cytotoxicity evaluation of curcumin treatment in DH82 canine histiocytic sarcoma cell line
}

\author{
Natália Noronha*, Gabriel Silva, Ana Lucia Fachin, Mozart Marins \\ From 5th Congress of the Brazilian Biotechnology Society (SBBIOTEC) \\ Florianópolis, Brazil. 10-14 November 2013
}

\section{Background}

The identification of targets and new drugs to fight cancer is one the greatest challenges for Biotechnology researchers. Not only humans, but also animals are affected by this disease. It is estimated for example that one in every 3-4 dogs will develop some type of cancer during its lifetime, twice as much as the human being $[1,2]$. DNA methylation is an important epigenetic mechanism which control gene expression during cell proliferation and differentiation. Deregulation of this mechanism is one of the events which can contribute to the development of cancer [3]. The identification of epigenetic drugs, which are molecules that can revert aberrant DNA methylation, is one of the main areas of cancer research nowadays. In this regard, natural products are a rich source of possibilities to increase the arsenal of epigenetic drugs [1]. This study aims to analyze the cytotoxicity effect of curcumin treatments in DH82 canine histiocytic sarcoma cell line. This polyphenol derived from Curcuma longa has emerged as a potent multimodal cancer-preventing agent which modulates multiple cell signaling pathways and also been described as an inhibitor of DNA methylation[4]. The knowledge of the biological effects of these substances can pinpoint targets for the development of epigenetic drugs, with a positive impact for the treatment of canine and human cancer.

\section{Materials and methods}

DH82 cells grew under $37^{\circ} \mathrm{C}$ and $5 \% \mathrm{CO}_{2}$, DMEM medium was supplemented with $10 \%$ Bovine Fetal Serum. To estimate DH82 viability and curcumin cytotoxicity, the MTT protocol was performed at a concentration of $2 \times 10^{5}$ cells/well cultured in 96 well plates. After each treatment, the cells were incubated during four hours

$$
\text { Department of Biotechnology, University of Ribeirão Preto, 14096-900, }
$$$$
\text { Ribeirão Preto, São Paulo, Brazil }
$$

with a $5 \mu \mathrm{g} / \mathrm{mL}$ MTT $(3-(4,5$-dimethylthiazol-2-yl) -2,5-diphenyltetrazolium bromide) solution. Lastly the MTT salt conversion to formazan crystals was quantified by spectrophotometry.

A curcumin therapeutic dose curve was established at 24, 48 and 72 hours treatments.

\section{Results and discussions}

In 24 hours, the $\mathrm{IC}_{50}$ was $21.88 \mu \mathrm{g} / \mathrm{mL}(59.4 \mu \mathrm{M})$, in 48 hours was $14.26 \mu \mathrm{g} / \mathrm{mL}(38.7 \mu \mathrm{M})$ and in 72 hours was $12.17 \mu \mathrm{g} / \mathrm{mL}(33.0 \mu \mathrm{M})$. A range of values were obtained and the dispersion, especially on $\mathrm{IC}_{50}$ coordinate coincides with the trend line, showing good positive correlation.

\section{Conclusions}

The DH82 cell line demonstrated susceptibility to treatments with curcumin, which reflects the importance of this natural product as a tool for the development of new epigenetic drugs which could be also explored to fight cancer in pet dogs.

\section{Financial support}

This study was supported by grants from Research Foundation of the State of São Paulo (FAPESP - 2012/ 23333-2).

\section{Published: 1 October 2014}

\section{References} chemopreventive compounds and canine cancer. Veterinary pathology 9, 46:576-588.

Sambucco PL, Sestito $V$ Tanara $G$ Bocchini $V$. Cancer incidence in pet dogs: findings of the Animal Tumor Registry of Genoa, Italy. Journal of veterinary internal medicine / American College of Veterinary Internal Medicine 2008, 22:976-984.

Ma X, Wang YW, Zhang MQ, Gazdar AF: DNA methylation data analysis and its application to cancer research. Epigenomics 2013, 5:301-316.
Baek SJ, McEntee MF, Legendre AM: Review paper: Cance 
4. Fu S, Kurzrock R: Development of curcumin as an epigenetic agent. Cancer 2010, 116:4670-4676.

doi:10.1186/1753-6561-8-S4-P138

Cite this article as: Noronha et al:: Cytotoxicity evaluation of curcumin

treatment in DH82 canine histiocytic sarcoma cell line. BMC Proceedings 2014 8(Suppl 4):P138.

Submit your next manuscript to BioMed Central and take full advantage of:

- Convenient online submission

- Thorough peer review

- No space constraints or color figure charges

- Immediate publication on acceptance

- Inclusion in PubMed, CAS, Scopus and Google Scholar

- Research which is freely available for redistribution

Submit your manuscript at www.biomedcentral.com/submit

() Biomed Central 